\title{
Histological and Scanning Electron Microscopic Studies on the Sensory Organs of the Terrestrial Flatworm Bipalium kewense
}

\author{
Abdel-Haleem AA ${ }^{1,2 *}$, Beltagi $\mathbf{S M}^{1}$ and Ali AS $^{1}$ \\ ${ }^{1}$ Department of Biology and Geology, Faculty of Education - Ain Shams University, Cairo, Egypt \\ ${ }^{2}$ Department of Biology, Faculty of Science \& Arts, Rafha, Northern Borders University, Saudi Arabia
}

\begin{abstract}
The present work investigated histological and cytological studies, using SEM, included sensory organs of flatworm Bipalium kewense. The shovel-headplate of $B$. kewense is limited all around its margin by distinct sensory organs, consisting of a row of sensory papillae, pits and eyespots. Sensory papillae and sensory pits are situated at the peripheral edge of worm-head whereas numerous eyespots are located within the margin of the dorsal shovelheadplate and along the body margin. Each eye is composed of pigment cells surrounding half moon-like lens and retinal cells. The present results suggested that the sensory papillae and pits are chemo-receptors.
\end{abstract}

Keywords: Land planarian; Bipalium sp; Sensory organs; Eyespots; SEM; Histology

\section{Introduction}

The shovel-headed garden flatworm, Bipalium kewense (Bipalliidae, Terricola, Turbellaria, Platyhelminthes) had locally collected in 2012 from the botanical garden of the faculty of Education, Ain Shams University, Cairo, Egypt [1].

Ultrastructural aspects of sensory papillae of land planarians have received little attention [2,3]. Land planarians have a great economic importance but histological and ultrastructural studies are insufficient and covered only too limited parts of the taxa [4].

Thereby, terrestrial triclads have become a subject of great concern in certain locations as predators of earthworms, and also due to a high proliferative rate. The present work deals with histological and ultrastructural studies, using SEM, on the sensory organs, including sensory papillae and eyespots, to reveal their fine structures and functions.

\section{Materials and Methods}

\section{Rearing}

Mature specimens of $B$. kewense [5], 9-11 cm in length, were collected locally from the University campus under boards, leaves and flagstones. They were reared within closed pots in the laboratory, weekly fed with live earthworms. Headplates were used for the present experiments.

\section{Histological study}

Fresh specimens of B. kewense had been fixed in alcoholic Bouin's fixative, dehydrated in ethyl alcohol, cleared in xylene and finally embedded in paraffin wax. Serial sections $(6-8 \mu)$ had been prepared, stained with haematoxylin and eosin, dehydrated in ethyl alcohol, cleared in cedar wood oil and mounted in Canada balsam. Finally, photomicrographs were taken using a microscope attached with an automatic camera.

\section{Scanning electron microscopy (SEM)}

B. kwense worms were fixed in $4 \%$ gluteraldehyde in $0.1 \mathrm{M}$ sodium cacodylate buffer ( $\mathrm{pH} 7.3$ ) for at least 48 hours and then washed for at least 1.5 hours with three changes of the same buffer, as recommended by [6]. Then, post-fixation was carried out in $1 \%$ osmium tetraoxide in the same buffer for at least 2 hours. The fixed specimens were washed in the same buffer for more 30 minutes. Dehydration of the specimens was carried out through a graded series of ethanol. Afterwards, the specimens were completely dried through the Critical Point Dryer with liquid $\mathrm{CO}_{2}$, mounted on copper stubs with double-sides adhesive tape and coated with gold using Sputter Coater S. 150A Edwards-England. Finally, the specimens were examined under JXA-840A Electron Probe Microanalyzer-JEOL-JAPAN.

\section{Results}

The fine structure of the present work revealed that sensory margin of the headplate of the land planarian $B$. kewense consists of a regular row of flattened sensory papillae and pits. The sensory papilla measures about $15 \times 25 \mu \mathrm{m}$ whereas pits vary between $15-35 \mu \mathrm{m}$ in depth, depending on the plane of sectioning as detecting in (Figures 1-3).

In details, sensory papillae are situated at the peripheral edge of the shovel-head (Figures 1-3), whereas each sensory pit is flask-shaped, usually originated from a depressed ciliated epidermis or lined by ciliated submerged epithelium through which a nerve penetrates to its blind end and is encircled by fine easinophilic gland cells. Each pit interconnected with others to open in the lateral as well as median ventral neuro-sensory pit, as described in (Figures 4-6).

On the other hand, the present works detected that the B. kewense possesses numerous eyespots distributed on the margin of the dorsal lunate-head as well as on the two lateral margins in row to the posterior end of the body. Each eye is dark brown in colour, simple pigment-cup typed, composed of a pigment cup which consists of numerous small pigment cells surrounding half moon-like lens and several retinal cells (Figures 3 and 7).

*Corresponding author: Abdel-Haleem AA, Department of Biology, Faculty of Science \& Arts, Rafha, Northern Borders University, Saudi Arabia, Tel: 202 26831474; E-mail: abddelsalam1958@windowslive.com

Received January 27, 2014; Accepted March 27, 2014; Published March 29, 2014

Citation: Abdel-Haleem AA, Beltagi SM, Ali AS (2014) Histological and Scanning Electron Microscopic Studies on the Sensory Organs of the Terrestrial Flatworm Bipalium kewense. J Cytol Histol 5: 233. doi:10.4172/2157-7099.1000233

Copyright: (C) 2014 Abdel-Haleem AA, et al. This is an open-access article distributed under the terms of the Creative Commons Attribution License, which permits unrestricted use, distribution, and reproduction in any medium, provided the original author and source are credited. 
Citation: Abdel-Haleem AA, Beltagi SM, Ali AS (2014) Histological and Scanning Electron Microscopic Studies on the Sensory Organs of the Terrestrial Flatworm Bipalium kewense. J Cytol Histol 5: 233. doi:10.4172/2157-7099.1000233

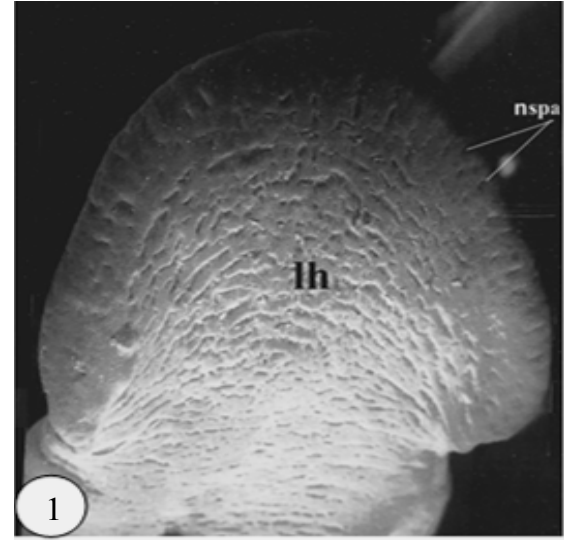

Figure 1: Scanning electron micrograph (SEM) showing dorsal view of the head region of terrestrial worm Bipalium kewense Moseley with expanded lunate head (Ih) and neuro-sensory papilla (nspa) (scale=1 $\mu$ ).

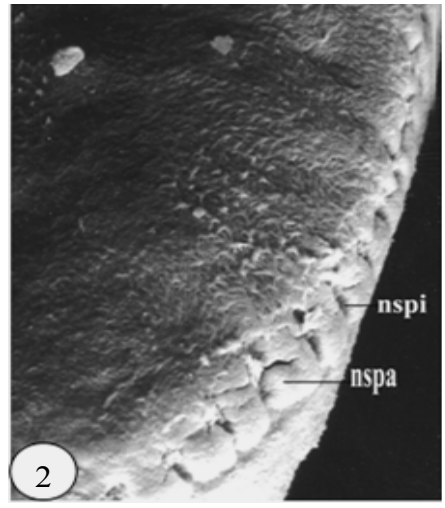

Figure 2: SEM of the head of B.kewense showing the distribution of neurosensory papillae (nspa) and neuro-sensory pits (nspi) on the dorsal surface of the head $($ scale $=1 \mu)$.

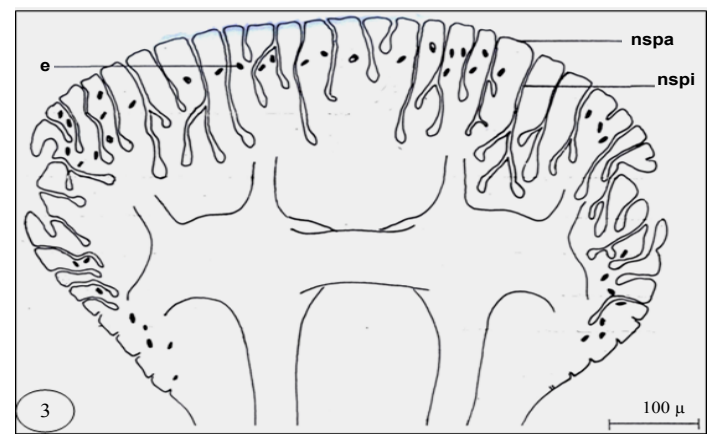

Figure 3: Diagrammatic representation of the dorsal surface of head region of B.kewense showing eyespots (e) neuro-sensory papillae (nspa) and neurosensory pits (nspi).

\section{Discussion}

Taxonomically, Winsor [7] studied the internal anatomy and histology of the terrestrial flatworms in family Bipaliidae and claimed that such sensory pits provided an important taxonomic characters.
Electron microscopic studies on terrestrial triclads are not numerous $[2,3,8,9]$

Fernandes et al. [10] reinforced the present measurements of

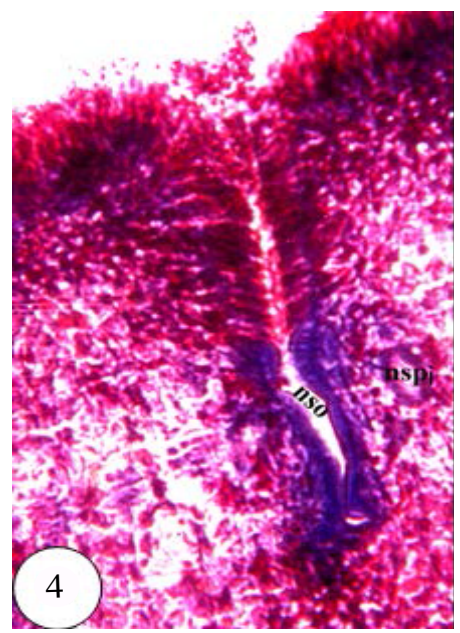

Figure 4: Photomicrograph of a part of T.S. of the head region of B. kewense showing an enlarged L.S. of neuro-sensory organ (nso), mucous gland cells (mgc) and T.S. in neuro-sensory pit (nspi) (H\&E., $X=320$ ).

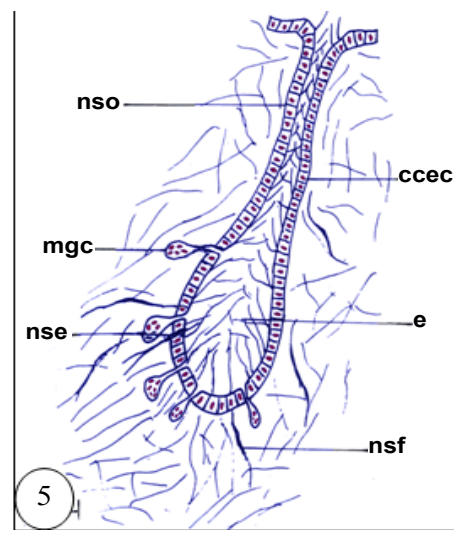

Figure 5: Diagrammatic representation of the neuro-sensory organ (nso) at the peripheral part of the headplate showing ciliated columnar epithelial cells (ccec), cilia (c), neuro-sensory cells (nsc), neuro-sensory fibres (nsf) and mucous gland cells $(\mathrm{mgc})$.

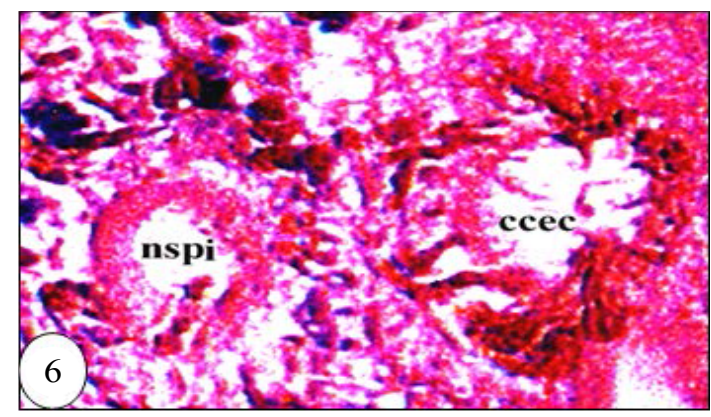

Figure 6: Photomicrograph of a part of T.S. of the head region of $B$. kewense showing an enlarged tube of neuro-sensory pit (nspi) that lined by ciliated columnar epithelial cells (ccec) (H\&E., $\mathrm{X}=880$ ). 


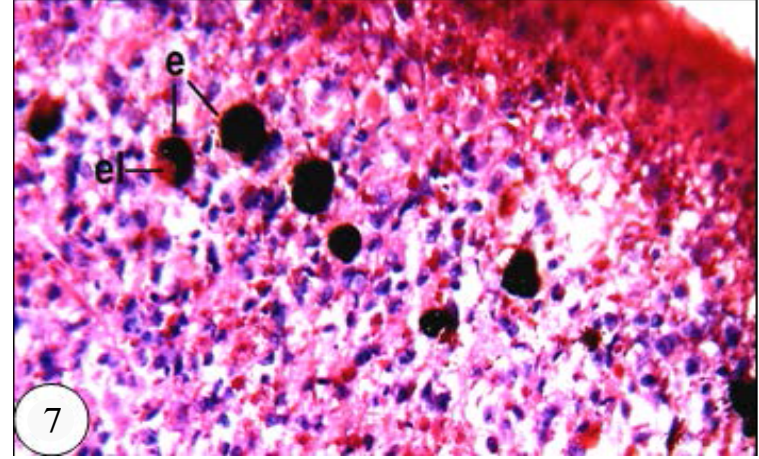

Figure7: Photomicrograph of a part of T.S. of the head region of $B$. kewense showing an enlarged eyespot (e) that is dark brown in colour and eye lens (el) that is half moon-shaped (H\&E., $X=600)$.

sensory papilla-width and sensory pit-depth in the same species, about $15 \times 25 \mu \mathrm{m}$ and $15-35 \mu \mathrm{m}$ respectively. Moreover, they found that pits are provided with sensory dendrites having long cilia and they interpreted as chemo-receptors and their immuno-histochemical experiment, by indirect immuno-fluorescence, confirmed their suggestion of the sensory function.

In the early, Hyman [11] found in the flatworms Stenostomum and Bothromesostoma that the chemoreceptors are mostly limited to the head region and comprise ciliated pits and their variants, which are depressed epidermal areas devoid of rhabdoits.

The present study confirms the function of sensory organs, as chemoreceptors, as declared by Storch and Abraham [3] and Fernandes et al. [10].

In this respect, Winsor [12] revealed that many eyes of $B$. kewense are distributed within the margin of the dorsal headplate as well as on the lateral margin right and left in row to the posterior end of the body. He detected that the eyes are dark brown in colour, pigment cupshaped and located dorso-posteriorly to the brain mass. Also, Jones and Gerard [13] found that eye arrangement is employed as an important taxonomic character in the land planarians.

The present results reinforced the studies of Winsor [12] and it could be suggested that the sensory papillae and sensory pits may be olfactory or chemoreceptors to test food, humidity and salinity of the surrounding environment, which is in line with observations that chemo-receptors are well developed among turbellarians.

On the other hand, Hyman [11] had early displayed eyespotstructure of land planarians as a pigment-cup ocellus consists of more pigment cells and many photosensitive neuro-sensory cells or retinal cells projecting from the cup through its opening and eyespot has half moon-like lens and the eye-chamber is slightly oval with bipolar retinal nerve cells having rounded ends, expanded into the cup and the proximal sensory fibre joins with the central nervous system. In this respect, Fernandes [10] had suggested that neuropeptide of $B$. kewense is present around the eyespots.

\section{References}

1. Ali AS (2008) Biological, histological, physiological and ultrastructural studies on terrestrial turbellarian Bipalium kewense, 1st record in Egypt. Ph.D Thesis, Ain Shams University, Cairo.

2. Storch V, Abraham R (1972) [Electron microscopic observations on the sensory border of the land-dwelling turbellarian Bipalium kewense Moseley (Tricladida)]. Z Zellforsch Mikrosk Anat 133: 267-275.

3. Curtis SK, Cowden RR, Moore JD, Robertson JL (1983) Histochemical and ultrastructural features of the epidermis of the land planarian Bipalium adventitium. J Morph.175: 171-194.

4. Cork J (2009) Shovel-headed Garden Worm. Australian Museum contact forms

5. Moseley HN (1878) Notes on the structure of several forms of land planarians with a description of two new genera and several new species, and a list of all species at present known. J Microsc. Sci 17: 273-292.

6. REYNOLDS ES (1963) The use of lead citrate at high $\mathrm{pH}$ as an electronopaque stain in electron microscopy. J Cell Biol 17: 208-212.

7. Winsor L (1997) A revision of the cosmopolitan land planarian Bipalium kewense (Turbellaria: Tricladida: Terricola). Zoological Journal of the Linnean Society 79: 61-100.

8. Bautz A (1977) Structure fine de l'epiderme chez des planaires triclades terrestre et paludicoles. Arch. Zool. exp. g'en. 118: 155-172.

9. McGee C, Fairweather I, Blackshaw RP (1997) Ultrastructural observations on rhabdite formation in the planarian, Artioposthia triangulata. J Zool Lond 240: 563-572

10. Fernandes MC, Alvares EP, Gama P, Silveiral M (2001) The sensory border of the land planarian Bipalium kewense (Tricladida, Terricola). Belg J Zool I3| 173-178.

11. Hyman LH (1940) Native and introduced land planarians in the united states. Science 92: 105-106.

12. Winsor L (1985) Land planarians (Turbellaria: Tricladida: Terricola). Introduced into Australia Bipalium kewense (Moseley, 1878). Victorian Nat 103: 3.

13. Jones HD, Gerard BM (1999) A new genus and species of terrestrial planarian (Platyhelminthes; Tricladida; Terricola) from Scotland, and an emendation of the genus Artioposthia. Journal of Natural History 33: 387-394. 